\title{
Analisis Pertanggungjawaban Pidana Bagi Pelaku Tenaga Pendidik Dalam Melakukan Kejahatan Pencabulan terhadap Anak (Studi Putusan Nomor 75/PID.SUS/2020/PN Metro)
}

\author{
Margaretha Laurinsque L.T ${ }^{1 *}$, Erna Dewi ${ }^{2}$, Indah Satria ${ }^{3}$ \\ ${ }^{1,2,3}$ Fakultas Hukum Universitas Bandar Lampung \\ Jalan Za. Pagar Alam No.29, Labuhan Ratu, Kec. Kedaton, Kota Bandar Lampung, Lampung 35142, Indonesia \\ *Correspondence email: margarethalaurinsque@gmail.com
}

\begin{abstract}
Abstrak. Pencabulan mewujudkan kekufuran esa berasal kelaliman seksual yang diakibatkan berasal adanya deformasi yang kelahirannya bagian dalam figur khalayak kita. Pencabulan adalah rupa kelaliman yang berlaga sangat lesu terutama muka korbannya, terlebih lagi jika korbannya berupa anak karena anak adalah penerus masa depan atau bisa di sebut penerus bangsa sebab pencabulan akan melanggar hak asasi manusia serta dapat merusak martabat kemanusiaan, khususnya terhadap jiwa, akal dan keturunan. Permasalahan dalam penelitian ini adalah apa faktor yang mempengaruhi pelaku melakukan tindak pidana penncabulan Anak dan bagaimana pertanggungjawabannya berdasarkan Putusan Nomor 75/Pid.Sus/2020/PN Metro. Metode penelitian menggunakan dalam penulisan Jurnal penelitian ini ialah Pedekatan yuridis normatif dan pendekatan empiris. Berdasakan hasil penelitian factor penyebab Pelaku melakukan kejahatan pencabulan terhadap anak ini antara lain Faktor keagamaan dimana iman terdakwa di sini goyah dan tergoda oleh godaan duniawi, Yang kedua faktor IPTEK dimana pelaku menyalahgunakan perkembangan kemajuan ternologi dengan melihat hal-hal yang tidak baik dan faktor itulah yang menyebabkan terjadinya pencabulan.
\end{abstract}

Kata Kunci: Tenaga Pendidik; Anak; Pencabulan; Tindak Pidana

Abstract. Fornication embodies the kufr one comes from sexual tyranny which results from the existence of deformations that give birth to a part in the figure of our audience. Fornication is a form of cruelty that plays very sluggishly, especially in the face of the victim, especially if the victim is a child because the child is the future successor or can be called the successor of the nation because sexual immorality will violate human rights and can damage human dignity, especially for the soul, reason and descendants. The problem in this research is what factors influence the criminal act of child molestation and how the accountability is based on Decision Number 75 / Pid.Sus / 2020 / PN Metro. The research method using this research journal is a normative juridical approach and an empirical approach. Based on the results of the research, the factors causing the perpetrator to commit the crime of sexual immorality against this child include religious factors where the faith of the defendant is shaky and tempted by worldly temptations. the occurrence of sexual immorality.

Keywords: Educators; Child; Fornication; Criminal act

\section{PENDAHULUAN}

Negara Indonesia merupakan negara yang menjunjung tinggi hukum. Hukum adalah kekuasaan yang mengatur dan memaksa serta mempunyai sanksi yang tegas bagi siapa yang melanggarnya. Pada hakekatnya tujuan diciptakan hukum agar tercipta kerukunan dan perdamaian dalam pergaulan hidup masyarakat. Namun pada kenyataannya dalam masyarakat masih bermunculan berbagai kejahatan. Ini menunjukkan bahwa tujuan hukum itu belum terwujud sepenuhnya.

Fenomena kelaliman itu akan selalu dijumpai bagian dalam pekerjaan sehari-hari. Setiap jiwa bagian dalam kehidupannya wajib akan selalu memiliki tekad kepada mengasese kebutuhannya, jika maksud akan babak itu tidak terlampiaskan dongeng bagian dalam jasmani orang inisiatif yang akan keluih ialah butuh mengasese kebutuhannya itu walaupun pakai menyandarkan segala lembaga dan bahkan lembaga-lembaga yang tidak benar. ${ }^{1}$ Pidana adalah serbuan etik-etik bagian dalam tiga loka sifat lain, yaitu sifat perdata, sifat ketatanegaraan, dan sifat susunan saham pemerintah, yang oleh penyusun Undang-cabut ditanggapi pakai suatu anutan pidana. ${ }^{2}$

Alasan pengakuan terhadap eksistensi kejahatan tersebut karena, kejahatan merupakan bentuk tingkah laku manusia yang sangat merugikan masyarakat, seperti kejahatan kesusilaan yang meliputi pemerkosaan, pencabulan, pelecehan seksual dan lain-lain. Kejahatan kesusilaan (misdrijven tegen de zeden) mengadakan kelaliman yang cukup menjangkau minat dikalangan masyarakat, jadi berasal seringnya diberitakan tindak pidana perkosaan dan agresi di kendaraan-kendaraan elektronik dan cetak. Salah esa sepak terjang yang dilarang oleh lembaga kekejian adalah agresi. Kitab Undang-Undang Hukum Pidana (KUHP) mencecahkan tindak pidana agresi ke bagian dalam tindak pidana

\footnotetext{
${ }^{1}$ Wirjono Projodikoro. 2003.Tindak Pidana Tertentu di Indonesia. Refika Aditama. Bandung, hlm. 52.

2 . Ibid., hlm. 8.
} 
kesusilaan. KUHP belum mengembangkan pakai kategoris niat berasal agresi itu orang dan terbayangkan mengebur adukkan pengertiannya pakai perkosaan atau persetubuhan.

Pencabulan menjadikan keingkaran tunggal mulai sejak onar seksual yang diakibatkan mulai sejak adanya deformasi yang kelahirannya bagian dalam konstruksi biasa kita. Pencabulan adalah rupa onar yang beradu sangat lesu terutama dekat korbannya, pasal penyerangan akan menyangkal hoki asasi pribadi bisa menghancurkan tingkatan kemanusiaan, khususnya terhadap jiwa, rasio dan keturunan. Cabul menjadikan sikap yang tidak senonoh bagian dalam jagat seksual, misalnya sikap merabaraba aurat yang dilakukan di sadar khalayak yang melahirkan stimulan berahi. Korban bagian dalam onar ini seringkali adalah bocah-bocah. Anak menjadikan pengganti reka-rekaan-rekarekaan penentangan suatu anak. Selain itu, bocah menjadikan sandaran orangtua, Setiap bocah harus mencengkaukan restorasi sejak dini, bocah terlazim merenggut jalan yang seluas-luasnya kepada bisa meningkat dan bertambah secara optimal, ketakziman fisik, lubuk moral maupun sosial. Terlebih lagi bahwa era keturunan menjadikan seratus tahun pendirian watak, kepribadian dan etika jasmani seorang pribadi, agar denyut berjerih payah memegang ketajaman dan anugerah kintil terlihat tegar bagian dalam denyut.

Anak adalah tingkatan pengganti kaum yang memegang ketergantungan bagian dalam mengerti dan menjaga awak berpunca berbagai reaksi pokok yang ada. Begitu juga tambah Undang-Undang Nomor 23 Tahun 2002 perihal Perindungan Anak adalah seseorang yang belum berusia 18 perian bahkan yang masih bagian dalam kandungan. Ketika budak bekerja target tindak pidana, langit harus merelakan sumbangsih kepadanya. Secara sifat langit Indonesia sangkil merelakan sumbangsih untuk budak menyeberangi berbagai pokok perundang-anggapan diantaranya Undang-Undang Nomor 17 Tahun 2016 perihal Perubahan Kedua Atas Undang-Undang Nomor 23 Tahun 2002 perihal Perlindungan Anak. Agar terwujudnya pokok buntut pribadi Indonesia yang bermartabat dan mampu membela menimbrung menanggung deretan dan aliansi kaum bagian dalam bekas Negara Kesatuan Republik Indonesia yang berlandasan Pancasila dan Undang-Undang Dasar 1945, diperlukan restorasi secara melantas berlinang demi kontinuitas hidup, kemajuan dan perputaran fisik, mental, dan sosial menimbrung sumbangsih berpunca segala kans yang akan memanaskan budak dan kaum dimasa depan.

Ubi societas ibi ius, dimana ada masyarakat disitu ada hukum yang berarti pula setiap masyarakat memiliki cara-cara berhukum sendiri yang tidak dapat dipaksakan begitu saja dari dan oleh bangsa lain. ${ }^{3}$

Berbagai macam aturan dibuat dengan tujuan untuk menjaga perilaku manusia agar selalu berakhlaq terpuji, tidak berbuat kerusakan, serta kemaksiatan. Meskipun pada dasarnya manusia itu diciptakan berkecenderungan terhadap kebaikan, namun sekali-kali manusia itu juga mempunyai sisi negatifnya yaitu suka berbuat kerusakan. Sehingga menimbulkan beberapa permasalahan dengan sesama manusia bahkan terhadap lingkungan di sekitarnya. ${ }^{4}$

Untuk meluluskan suatu tingkah laku seperti suatu tindak pidana, KUHP menuntut adanya elemen-elemen ukuran yang harus dipenuhi, yaitu lembaga membangkang kebiasaan dan kejahatan. Sifat membangkang kebiasaan selalu mengkover suatu tindak pidana, ketakziman lembaga membangkang kebiasaan terkandung secara spesifik terselip bagian dalam kerangka tindak pidana maupun tidak terselip secara spesifik bagian dalam kerangka tindak pidana. Unsur kejahatan selalu mengkover suatu tindak pidana, ketakziman secara spesifik terselip bagian dalam kerangka tindak pidana maupun tidak terselip secara spesifik bagian dalam kerangka tindak pidana, kecuali bagian dalam kerangka tindak pidana sedia elemen kealpaan. Agar terlampiaskan suatu tingkah laku seperti suatu tindak pidana harus meluluskan elemen lembaga membangkang kebiasaan dan kejahatan.

Salah satu perkara Tindak Pidana Pencabulan yang dilakukan oleh tenaga pendidik terhadap anak adalah seperti dalam Putusan Pengadilan Negeri Metro Nomor 75Pid.sus/2020. Kasus tersebut dilakukan oleh Terdakwa Jus Juansyah Bin Jumani, dimana Majelis Hakim Pengadilan Negeri Metro memutuskan Menyatakan terdakwa telah terbukti secara sah dan meyakinkan bersalah melakukan tindak pidana " Pencabulan terhadap anak"; pada Hari Rabu Tanggal 03 Juni 2020 sekira atau setidaknya pada suatu waktu dalam Bulan juni 2020 bertempat di Jalan Batu Kelurahan Ganjarasri Kecamatan Metro Barat Kota Metro atau setidak-tidaknya pada suatu tempat lain yang masih termasuk dalam daerah hukum Pengadilan Negeri Metro yang melakukan, perbuatan pencabulan dengan maksud untuk menguntungkan diri memenuhi hasrat atau orang lain secara melawan hukum, memforsir seorang dengan kekerasan ataupun ancaman kekerasan buat membagikan benda suatu, yang seluruhnya ataupun sebagian merupakan milik orang itu ataupun orang lain ataupun biar membuat hutang ataupun menghapus piutang. Menjatuhkan pidana kepada tersangka dengan pidana penjara 6( 3 ) bulan, Menetapkan masa penangkapan serta penahanan yang sudah dijalani tersangka dikurangkan seluruhnya dari Pidana yang dijatuhkan; Menetapkan tersangka senantiasa ditahan; Membebankan kepada tersangka membayar bayaran masalah beberapa Rp. 2. 000. 00( 2 ribu rupiah);

Berdasarkan latar belakang diatas maka penulis tertarik meneliti jurnal yang berjudul Analisis Pertanggungjawaban Pidana Bagi Pelaku Tenaga Pendidik Dalam Melakukan Kejahatan Pencabulan Terhadap Anak (Studi Putusan Nomor 75/Pid.Sus/2020/Pn Metro)

\footnotetext{
${ }^{3}$ Suteki. 2013. Desain Hukum di Ruang Sosial.Thafa Media. Yogyakarta, hlm. 165-166.

${ }^{4}$ Adami Chazawi. 2010. Kejahatan Terhadap Tubuh dan Nyawa. Rajawali Pers. Jakarta, hlm 2
} 
Margaretha Laurinsque L.T, Erna Dewi dan Indah Satria, Analisis Pertanggungjawaban Pidana Bagi Pelaku Tenaga Pendidik dalam Melakukan Kejahatan Pencabulan terhadap Anak (Studi Putusan Nomor 75/PID.SUS/2020/PN Metro)

\section{Pengertian Anak}

Pengertian anak dalam hukum pidana lebih diutamakan pada pemahaman terhadap hak-hak anak yang harus dilindungi. Karena secara kodrat anak memiliki substansi yang lemah dan di dalam sistem hukum dipandang sebagai subjek hukum yang dicangkokkan dari bentuk pertanggungjawaban sebagaimana layaknya seorang subjek hukum yang normal.

Anak fragmen bagian dalam kerabat menemukan prakata bahagia, karena anggota menyerahkan ujung pangkal perbanyak warga tuanya. Arti di sini mengandung kegiatan menyerahkan isi, nilai, kepuasan, kebanggaan, dan advis perizinan konstituen yang disebabkan oleh keberhasilan warga tuanya yang taksiran memiliki keturunan, yang akan mempersembahkan semua maksud-maksud runggu dan presensi hidupnya. Anak dikonotasikan serupa badan yang belum menghambur kematangan fisik, kematangan sosial, kematangan pribadi dan kematangan mental. Kemudian racun dipahami bahwa anggota menemukan tunas, potensi, dan generasi ari substitusi maksud - maksud penolakan bocah, memiliki jasa strategis dan mempunyai perintah dan sifat terasing yang menjaga sirkulasi presensi bocah dan habitat fase seratus tahun depan. Oleh karna itu memelihara anggota menemukan pikulan semua warga.

\section{Pertanggungjawaban Pidana \\ Pertanggungjawaban Pidana Menurut KUHP}

Pertanggungjawaban Pidana Menurut Ketentuan Hukum Positif Perbuatan-tabiat kriminal memercayai peraturan KUHP kita kira pangkal kebengisan dan pelanggaran. Pelanggaran yang dimaksud yaitu tabiat-tabiat yang cara menampik hukumnya baru bisa tersua setelah tersua pokok yang menentukan. Perbuatan kriminal tidak terhitung pengenalan pertanggungjawaban kriminal.

Dilarang dan diancamnya perbuatan dengan suatu ancaman pidana. Apakah orang yang melakukan perbuatan kemudian dijatuhi pidana, tergantung kepada apakah dalam melakukan perbuatan itu orang tersebut memiliki kesalahan. $^{5}$

Dengan demikian, membicarakan pertanggungjawaban pidana mau tidak mau harus didahului dengan penjelasan tentang perbuatan pidana. Sebab seseorang tidak bisa dimintai pertanggungjawaban pidana tanpa terlebih dahulu ia melakukan perbuatan pidana. Adalah dirasakan tidak adil jika tiba-tiba seseorang harus bertanggung jawab atas suatu tindakan, sedang ia sendiri tidak melakukan tindakan tersebut. ${ }^{6}$

Pidana Penjara Berbeda dengan orang dewasa, pidana penjara bagi anak nakal lamanya $1 / 2$ (satu perdua) dari ancaman pidana orang dewasa atau paling lama 10 (sepuluh) tahun. Kecuali itu, pidana mati dan penjara seumur hidup tidak dapat dijatuhkan terhadap anak, sebagai gantinya adalah dijatuhkan salah satu tindakan. ${ }^{7}$

Teori Pertanggungjawaban Pidana Terdapat dua pandangan mengenai pertanggungjawaban pidana yaitu:

1. Teori Monoistis Teori monoistis ini dikemukakan oleh Simon yang merumuskan pertanggungjawaban pidana adalah suatu perbuatan yang oleh hukum diancam dengan hukuman, bertentangan dengan hukum, dilakukan oleh seorang yang bersalah dan dan orang itu dianggap bertanggung jawabatas perbuatannya. Menurut aliran ini unsurunsur Strafbaar Feit itu meliputi unsur perbuatan atau unsur objektif dan unsur pembuat atau sering disebut unsur subjektif. Oleh karena itu, dicampurnyaunsur perbuatan dengan unsur pembuat, maka dapat kita simpulkan bahwa Strafbaar Feit adalah sama dengan syarat-syarat penjatuhan pidana sehingga kalau terjadi Strafbaar Feit maka sudah pasti pelakunya dapat dipidana. ${ }^{8}$

2. Teori Dualistis Pandangan dualistis ini memisahkan antara perbuatan pidana dan petanggungjawaban pidana. Menurut pandangan ini, unsur objektif hanya dikandung dalam perbuatan pidana. Atas dasar inilah perbuatn pidana hanya dapat dilarang karena tidak mungkin suatu perbuatan dijatuhi pidana. Sedangkan, unsur subjektif hanya terkandung dalam pertanggungjawaban pidana yang ditujukan kepada pembuat. Oleh karena itu, pemidanaan hanya diterapkan kepada pembuat setelah terbukti melakukan perbuatan pidana dan dapat dipertanggungjawabkan atas perbuatan yang dilakukan. Pelaksanaan perbuatan pidana tidak serta merta membuat seseorang dapat dipidana, lantaran perbuatan pidana hanya merujuk kepada sifat perbuatn yang dilarang dan diancam dengan pidana apabila dilanggar.

\section{Pengertian dan Jenis-jenis Pidana}

Hukum pidana itu ialah hukum yang mengatur tentang pelanggaran -pelanggaran dan kejahatan-kejahatan terhadap kepentingan umum, perbuatan mana diancam dengan hukuman yang merupakan suatu penderitaan atau siksaan. Dalam Pasal 10 KUHP disebutkan pidana itu terdiri atas pidana pokok dan pidana tambahan. Pidana pokok

\footnotetext{
${ }^{5}$ Moeljatno. 2008. Asas-Asas Hukum Pidana. Rineka Cipta. Jakarta, hlm. 165.

${ }^{6}$ Mahrus Ali. 2011. Asas-Asas Hukum Pidana. Sinar Grafika. Jakarta, hlm. 155.

${ }^{7}$ Bambang Waluyo. 2000. Pidana dan Pemidanaan. Sinar Grafika. Jakarta, hlm. 29.

${ }^{8}$ Muladi dan Dwidja Priyatno. 2009.Pertanggungjawaban Pidana koorporasi. Kencana Media Group. Bandung, hlm.
}

61-63. 
Margaretha Laurinsque L.T, Erna Dewi dan Indah Satria, Analisis Pertanggungjawaban Pidana Bagi Pelaku Tenaga Pendidik dalam Melakukan Kejahatan Pencabulan terhadap Anak (Studi Putusan Nomor 75/PID.SUS/2020/PN Metro)

terdiri atas pidana mati, kurungan, denda dan tutupan. Sedangkan pidana tambahan terdiri atas pencabutan hak tertentu, perampasan barang tertentu, dan pengumuman putusan hakim.

\section{Pidana Mati}

Menarik untuk dipahami adalah jenis pidana mati, yang dalam rancangan KUHP baru disebut bersifar khusus. Penerapan pidana mati dalam praktek sering menimbulkan perdebatan diantara yang setuju dan yang tidak setuju. ${ }^{9}$

\section{Pidana Penjara}

Pidana penjara merupakan pidana pokok yang berwujud pengurangan atau perampasan kemerdekaan seseorang. Namun demikian, tujuan pidana penjara itu tidak hanya memberikan pembalasan terhadap perbuatan yang dilakukan dengan memberikan penderitaan kepada terpidana karena telah dirampas atau dihilangkan kemerdekaan bergeraknya, disamping itu juga mempunyai tujuan lain yaitu untuk membina dan membimbing terpidana agar dapat kembali menjadi anggota masyarakat yang baik dan berguna bagi masyarakat, bangsa dan negara.

Mengenai pidana penjara, Rusli Effendy. ${ }^{10}$

\section{Menyatakan bahwa " pidana Penjara Diancamkan Terhadap kejahatan-kejahatan bersengaja, kejahatan-} kejahatan culpa dan pelanggaran fiskal ”.

Dalam pasal 12 KUHP $^{11}$ diatur mengenai lamanya ancaman atau penjatuhan pidana penjara, yaitu :

(1) Hukaman penjara itu lamanya seumur hidup atau untuk sementara.

(2) Hukuman penjara sementara itu sekurang-kurangnya satu hari dan selama- lamanya lima belas tahun berturutturut.

(3) Hukuman penjara sementara boleh dihukum mati, penjara seumur hidup, dan penjara sementara, dan dalam hal lima belas tahun itu dilampaui, sebab hukuman ditambah, karna ada gabungan kejahatan atau karna aturan pasal 52.

(4) Lamanya hukuman sementara itu sekali-kali tidak boleh lebih dari dua puluh tahun.

\section{Pidana Kurungan}

Pidana kutungan merupakan pidana yang lebih ringan daripada pidana penjara yang diperuntukkan bagi peristiwa-peristiwa pidana yang lebih ringan sifatnya, dalam hal bagi mereka yang melakukan pelanggaranpelanggaran yang sebagaimana telah diatur dalam Buku III KUHP serta bagi mereka yang melakukan kejahatankejahatan yang tidak disengaja sebagaimana yang telah diatur dalam Buku II KUHP.Menurut pasal 18 KUHP, pidana kurungan minimal satu hari dan maksimal satu tahun dan dapat diperpanjang menjadi satu tahun empat bulan jika terdapat atau terjadi gabungan delik, berulang kali melakukan delik dan terkena rumusan ketentuan pasal 52 KUHP.

Dalam beberapa hal , pidana kurungan adalah sama dengan pidana penjara yaitu: ${ }^{12}$

1. Sama, berupa pidana hilang kemerdekaan bergerak.

2. Mengenal maksimum umum, maksimum khusus, dan minimum umum, tapi tidak mengenal minimum khusus, maksimum umum pidana penjara 15 tahun yang karna alasan-alasan tertentu dapat diperpanjang menjadi maksimum 20 tahun, dan pidana kurungan 1 tahun yang dapat diperpanjang maksimum 1 tahun 4 bulan. Minimum umum pidana penjara maupun kurungan sama 1 hari. Sedangkan maksimum khusus disebutkan pada setiap rumusan tindak pidana tertentu sendiri-sendiri, yang tidak sama bagi semua tindak pidana, bergantung dari pertimbangan berat ringannya tindak pidana yang bersangkutan.

3. Orang yang dipidana kurungan dan pidana penjara diwajibkan untu menjalankan (bekerja) pekerjaan tertentu, walaupun untuk narapidana kurungan lebih ringan dibanding narapidan penjara.

\section{Pidana Denda}

Pidana denda adalah pidana yang berupa harta benda yang jumlah ancaman pidananya pada umumnya relatif ringan yang mana dirumuskan sebagai pokok pidana alternatif dari pidana penjara dan denda

${ }^{9}$ Bambang Waluyo. 2000. Pidana dan Pemidanaan. Sinar Grafika. Jakarta, hlm. 12.

${ }^{10}$ Ahmad Nindra Ferry. 2002. Efektifitas Sanksi Pidana Dalam Penanggulan Kejahatan. Psikotropika. Kota Makassar. Perpustakaan Unhas. Makassar, hlm.31

${ }^{11}$ R. Soesilo. 1989. Kitab Undang-Undang Hukum Pidana. Bogor: Politeia

12 Adami Chazawi. 2002,SH.Pelajaran Hukum Pidana Bagian I.Jakarta: Raja Grafindo Persada. 
Margaretha Laurinsque L.T, Erna Dewi dan Indah Satria, Analisis Pertanggungjawaban Pidana Bagi Pelaku Tenaga Pendidik dalam Melakukan Kejahatan Pencabulan terhadap Anak (Studi Putusan Nomor 75/PID.SUS/2020/PN Metro)

\section{Pidana Tutupan}

Pidana tutupan adalah merupakan jenis pidana yang baru dimasukkan dalam KUHP yang diatur dalam Undangundang Nomor 20 Tahun 1946 tanggal 31 Oktober 1946 dan menempati urutan kelima pada jenis-jenis pidana pokok seperti yang telah ada pada Pasal 10 huruf a KUHP.

\section{Pengertian dan Jenis-jenis Tindak Pidana}

Tindak pidana merupakan terjemahan dari pendekatan Strafbaar Feit atau delik dalam bahasa inggrisnya Criminal Act, ada beberapa bagian mengenai tindak pidana dan beberapa pendapat darri pakarpakar hukum pidana.

1. Menurut Simons, menyatakan tindak pidana ialah suatu tindakan atau perbuatan yang diancam dengan pidana oleh Undang-undang Hukum Pidana, bertentangan dengan hukum pidana dan dilakukan dengan kesalahan oleh seseorang yang mampu bertanggung jawab. ${ }^{13}$

2. Menurut E. Utrecht menyatakan tindak pidana ialah dengan istilah peristiwa pidana yang sering juga ia sebut delik, karena peristiwa itu merupakan suatu perbuatan atau sesuatu yang melalaikan maupun akibatnya (keadaan yang ditimbulkan karena perbuatan melalaikan itu). ${ }^{14}$

\section{Tujuan Hukum Pidana dan Jenis-jenis Tindak Pidana}

Aturan-aturan hukum pidana yang ada di dalam masyarakat, tentu saja untuk mewujudkan tujuan hukum. Keberadaan hukum tentunya sangat diharapkan dapat menertibkan dan mengatur kehidupan masyarakat. Seperti yang dikemukakan oleh Wirjono Prodikroro bahwa tujuan hukum adalah "untuk mengadakan keselamatan, kebahagiaan, dan tata tertib dalam masyarakat". ${ }^{15}$

Adapun jenis-jenis dari tindak pidana, ialah sebagai berikut:

1. Kejahatan dan pelanggaran

2. Kesengajaan dan kealpaan

3. Perbuatan yang melanggar Undang-undang

4. Delik formil (menitik beratkan pada perbuatan)

5. Delik tunggal (hanya dilakukan sekali dalam perbuatan)

6. Delik biasa (penuntutan bisa dilakukan tanpa adanya aduan).

\section{Tindak Pidana Pencabulan}

Tindak pidana pencabulan merupakan bagian dari kejahatan kesusilaan. Kejahatan adalah suatu kesalahan yang dipertimbangkan oleh pemerintah sebagai hal yang merugikan dan menyiksa masyarakat yang bersifat melanggar kaidah hukum pidana.

\section{Pencabulan Anak dan Pencabulan di Lingkungan Kerja}

Mengenai Pasal 294 Kitab Undang-Undang Hukum Pidana (“KUHP”) yang Anda sebutkan, berbunyi sebagai berikut:

1. Barang siapa melakukan perbuatan cabul dengan anaknya, anak tirinya, anak angkatnya, anak di bawah pengawasannya yang belum dewasa, anak tiri atau anak pungutnya, anak peliharaannya,atau dengan seorang yang belum dewasa yang dipercayakan padanya untuk ditanggung, dididik atau dijaga, atau dengan bujang atau orang sebawahnya yang belum dewasa, dihukum penjara paling lama tujuh tahun.

2. Diancam dengan pidana yang sama:

a. Pegawai negari yang melakukan perbuatan cabul dengan orang yang dibawah perintahnya atau dengan orang yang dipercayakan atau diserahkan kepadanya untuk dijaga;

b. pengurus, dokter, guru, pegawai, mandor (opzichter) pengawas atau pesuruh dalam penjara, tempat pekerjaan negara (landswerkinrichting), tempat pendidikan, rumah piatu, rumah sakit, rumah sakit jiwa atau lembaga sosial,

\section{Unsur-Unsur Pidana dalam Pasal 294 ayat (2) ke-2 KUHP}

Menjawab pertanyaan Anda, unsur-unsur pidana dalam Pasal 294 ayat (2) ke-2 KUHP adalah:

1. Barang siapa;

2. Melakukan perbuatan cabul terhadap orang (dewasa atau belum dewasa) yang dimasukkan ke dalamnya (satu lingkungan kerja/ institusi);

\footnotetext{
${ }^{13}$ Moeljatno. 2005. Asas-asas Hukum Pidana. Bina Aksara. Jakarta, hlm.20.

${ }^{14}$ Ibid

${ }^{15}$ R.Soersono. 1992. Pengantar Ilmu Hukum. Sinar Grafika. Bandung, hlm. 27
} 
3. Pelaku tindak pidananya adalah pengurus, dokter, guru, pegawai, pengawas atau pesuruh dalam penjara, orang yang berada pada tempat pekerjaan negara, tempat pendidikan, rumah piatu, rumah sakit, rumah sakit jiwa atau lembaga sosial.

Dasar Hukum:

A. Kitab Undang-Undang Hukum Pidana;

B. Undang-Undang Nomor 23 Tahun 2002 tentang Perlindungan Anak sebagaimana yang telah diubah oleh UndangUndang Nomor 35 tahun 2014 tentang Perubahan Atas Undang-Undang Nomor 23 Tahun 2002 tentang Perlindungan Anak dan diubah kedua kalinya dengan Peraturan Pemerintah Pengganti Undang-Undang Nomor 1 Tahun 2016 tentang Perubahan Kedua Atas Undang-Undang Nomor 23 Tahun 2002 tentang Perlindungan Anak sebagaimana yang telah ditetapkan sebagai undang-undang dengan Undang-Undang Nomor 17 Tahun 2016 tentang Penetapan Peraturan Pemerintah Pengganti Undang-Undang Nomor 1 Tahun 2016 tentang Perubahan Kedua Atas Undang-Undang Nomor 23 Tahun 2002 tentang Perlindungan Anak Menjadi Undang-Undang.

\section{Faktor-faktor yang mempengaruhi pelaku melakukan tindak pidana Pencabulan anak (Studi Putusan Nomor 75/Pid.Sus/2020/Pn. Metro)}

Hasil wawancara peneliti dengan salah satu Hakim di Pengadilan Negeri Metro yaitu Bapak Rakhmad Fajeri sekaligus salah satu majelis Hakim pada kasus nomor 75/Pid.Sus/2020/PN.Metro. Beliau mengemukakan bahwa: "Pencabulan anak di bawah umur terjadi karena faktor kenakalan korban sendiri, seperti berpakaian seksi dan menampakkan aurat secara berlebihan dan memiliki rupa yang cantik". ${ }^{16}$

Peneliti dapat menyimpulkan bahwa faktor-faktor selanjutnya yang menyebabkan pencabulan terhadap anak dibawah umur disebabkan oleh akibat yang ditimbulkan oleh korban juga, dari segi penggunaan pakaian yang seksi, karena wajah yang cantik dan diakibatkan oleh keadaan kondisi sendiri.

Sementara hasil wawancara penulis dengan Kejaksaan bagian Kepala Seksi Tindak Pidana Umum ( KASIPIDUM ) bapak Dwi Nanda Saputra, SH. MH Metro mengatakan bahwa faktor timbulnya tindak pidana pencabulan terhadap anak dibawah umur yaitu : "Faktor yang mempengaruhi terjadinya pencabulan anak di bawa umur karena kurangnya pemahaman agama dan kemajuan ilmu pengetahuan ilmu teknologi (IPTEK)." 17

Mengingat hal di atas, maka peneliti menyimpulkan bahwa fakor yang mempengaruhi tindak pidana pencabulan anak di bawah umur. Pertama, kurang pemahaman agama. Karena memang pemahaman agama merupakan ajaran kepercayaan yang diyakini oleh setiap manusia sebagai penuntun sikap dan prilaku untuk melakukan perintah-nya dan menjauhi larangan-nya. Dengan demikian apabila manusia menjalankan ajaran agama maka ia akan senantiasa menjadi manusia yang selalu melakukan hal-hal yang baik. Sebaliknya jika manusia jauh dari ajaran agama maka ia selalu melakukan perbuatan-perbuatan jahat. Kedua, pengaruh kemajuan ilmu pengetahuan teknologi (IPTEK) karena mengingat perkembangan ilmu pengtahuan dan teknologi (IPTEK) mempunya pengaruh yang besar bagi pertumbuhan dan kemajuan suatu bangsa. Namun perkembangan IPTEK tersebut banyak dimanfaatkan oleh orang yang tidak bertanggung jawab seperti dengan membuat situs-situs porno di internet, mengedarkan VCD dan majalah porno dan lain sebagainya. Sehingga hal tersebut sangat berpengaruh besar bagi pertumbuhan anak untuk melakukan kejahatan dan kesusilaan.

Jadi Faktor yang mempengaruhi terdakwa untuk melakukan pencabulan terhadap anak juga masuk kedalam faktor lingkungan, yang dimana itu juga mempengaruhi pergaulan seseorang melakukan aktifitasnya sehari-hari karena lingkuan dalam pergaulan itu menentukan kelakuan dan sifat kita dalam beraktifitas. Kemudian faktor yang mempengaruhi terdakwa masuk kedalam faktor keagaam, dimana iman terdakwa sangat lemah sehingga mudah tergoda olah godaan duniawi termasuk melakukan pencabulan terhadap anak dibwah umur . Kemudia faktor yang mempengaruhi terdakwa masuk dalam faktor kemajuan ilmu teknologi ( IPTEK ) dimana saudara terdakwa menggunakan kemajuaan ilmu teknologi tidak dipergunakan dengan sebaiknya seperti menonton video porno, melihat video tes uji rangsangan dan masih banyak lagi penggunaaan yang tidak baik, sehingga saudara terdakwa bisa melakukan percabulan tersebut. Adapun saudara terdakwapun memberikan keterangan pada saat penyelidikan dan menyatakan bahwa terdakwa melakukan hal tersebut dengan maksud keisengan dan dilakukan dalam keadaan sadar diri.

\section{Pertanggungjawaban Pidana Bagi Pelaku Tenaga Pendidik Dalam Melakukan Kejahatan Pencabulan Terhadap Anak (Studi Putusan Nomor 75/Pid.Sus/2020/Pn. Metro)}

Berdasarkan hasil penelitian dengan Bapak Dwi Nanda Saputra selaku Kepala Seksi Tindak Pidana Umum di Kejaksaan Negeri Metro, beliau mengatakan bahwa di dalam hukum pidana, pertanggungjawaban pidana merupakan

\footnotetext{
${ }^{16}$ Rakhmad Fajeri (Majelis Hakim), Wawancara, Metro 27 Desember 2020

${ }^{17}$ Dwi Nanda Saputra ( Kasipidun ), Wawancara, Metro 06 Januari 2021
} 
konsep sentralyang dikenal dengan ajaran kesalahan. Dalam bahasa latin ajaran kesalahan dikenal dengan sebutan mens rea. Mens rea didasarkanpada suatu perbuatan yang mengakibatkan seseorang bersalahjika pikiran orang itu jahat. Berdasarkan asas tersebut, ada dua syarat yang harus dipenuhi untuk dapat memidanakan seseorang, yaitu ada perbuatan lahiriah yang terlarang/perbuatan pidana (actus reus), dan ada sikap batin jahat/tercela (mens rea).

Undang-Undang Nomor 23 Tahun 2002 tentang Perlindungan Anak sebagai acuan menjerat pelaku tindak pidana pencabulan. Pelaku pencabulan tidak lagi dijerat dengan pasal-pasal yang termuat dalam KUHP, namun lebih khusus diterapkan Undang-Undang Nomor 23 Tahun 2002 tentang Perlindungan Anak.Hal ini sejalan dengan asas lex specialis derogat legi generalis, yang artinya Undang - Undang Khusus Undang - Undang Nomor 23 tahun 2002 tentang Perlindungan mengesampingkan Undang-Undang yang bersifat umum (KUHP).

Menurut Pasal 82 ini dapat dihukum setiap orang yang dengan sengaja baik dengan kekerasan maupun dengan melakukan kebohongan, tipu muslihat dan bujukan terhadap anak di bawah umur belum berusia 18 (delapan belas) tahun untuk melakukan segala perbuatan yang bertentangan dengan kesusilaan dan kehormatan anak atau korban dan membiarkan dilakukannya perbuatan yang bertentangan dengan kesusilaan dan kehormatan anak oleh orang lain. Misalnya meraba-raba kemaluan atau anggota tubuh korban, menciumi korban dan lain sebagainya.

Unsur-unsur yang harus dipenuhi, berdasarkan rumusan Pasal 82 Undang-undang Nomor 35 tahun 2014 tentang perubahan Undang-undang No. 23 tahun 2002, maka unsur-unsur yang harus dipenuhi dalam menerapkan kekerasan seksual terhadap anak adalah:

1. Adanya kekerasan atau ancaman kekerasan.

2. Adanya tipu muslihat.

3. Adanya serangkaian kebohongan.

4. Adanya bujukan.

5. Adanya pencabulan dengan seorang anak.

Unsur-unsur yang harus dipertimbangkan oleh hakim untuk menentukan pertanggungjawaban pidana adalah:

1. Sifat melawan hukum yang dilakukan penilaian secara teleologis dan bukan unsur tindak pidana.

2. Kesalahan yang dilakukan penilaian secara teleologis dan bukan sebagai unsur tindak pidana.

3. Tidak ada alasan pembenar.

4. Tidak ada alasan pemaaf.

5. Mampu bertanggung jawab.

\section{SIMPULAN}

Berdasarkan hasil penelitian dan pembahasan maka dapat ditarik kesimpulan sebagai berikut:

1. Faktor yang mempengaruhi terdakwa dalam Putusan Nomor 75/pid.sus/2020/PN.Metro terhadap siswinya, terdakwa melakukan kejahatan pencabulan masuk dalam faktor keagaman, dimana iman terdakwa sangat lemah sehingga mudah tergoda oleh godaan duniawi sehingga melakukan pencabulan terhadap anak yang korbannya merupakan siswinya sendiri. Kemudian ada lagi faktor terdakwa, masuk dalam faktor kemajuan ilmu teknologi (IPTEK) dimana terdakwa menggunakan kemajuaan ilmu teknologi tidak dipergunakan dengan sebaiknya seperti menonton video porno, melihat video tes uji rangsangan dan masih banyak lagi penggunaaan yang tidak baik, sehingga saudara terdakwa bisa melakukan percabulan tersebut. Adapun saudara terdakwapun memberikan keterangan pada saat penyelidikan dan menyatakan bahwa terdakwa melakukan hal tersebut dengan maksud keisengan dan dilakukan dalam keadaan sadar diri.

2. Pertanggungjawabaan pidana bagi terdakwa dalam putusan Nomor 75/Pid.Sus/2020/PN.Metro terhadap siswinya yang melakukan kejahatan pencabulan bahwa untuk menjatuhkan pidana terhadap Terdakwa, maka perlu dipertimbangkan terlebih dahulu keadaan yang memberatkan dan yang meringankan Terdakwa. Keadaan yang memberatkan Perbuatan Terdakwa merusak masa depan generasi penerus bangsa. Keadaan yang meringankan Terdakwa bersikap sopan di persidangan dan menyesali perbuatannya. Bahwa oleh karena Terdakwa dijatuhi pidana maka haruslah dibebani pula untuk membayar biaya perkara sebagaimana pada pasal Pasal 82 ayat (1) dan ayat (2) Jo. Pasal 76E Undang-Undang Nomor 35 Tahun 2014 tentang Perubahan atas Undang-Undang Nomor 23 Tahun 2002 tentang Perlindungan Anak Jo. Undang-Undang Nomor 17 Tahun 2016 tentang Penetapan Peraturan Pemerintah Pengganti Undang-Undang Nomor 1 Tahun 2016 tentang Perubahan Kedua atas Undang-Undang Nomor 23 Tahun 2002 tentang Perlindungan Anak menjadi Undang-Undang serta Undang-Undang Nomor 8 Tahun 1981 Tentang Hukum Acara Pidana serta peraturan perundang-undangan lain yang bersangkutan yang berisikan tentang penyatakan terdakwa telah terbukti secara sah dan meyakinkan bersalah melakukan tindak pidana "melakukan perbuatan cabul terhadap anak yang dilakukan oleh pendidik atau tenaga kependidikan"; dijatuhi pidana penjara terhadap Terdakwa tersebut di atas oleh karena itu dengan pidana penjara selama 6 (enam) Tahun serta denda sejumlah Rp1.000.000.000,00 (satu miliar rupiah) dengan ketentuan apabila denda tersebut tidak dibayar diganti dengan pidana kurungan selama 3 (tiga) Bulan. 
Margaretha Laurinsque L.T, Erna Dewi dan Indah Satria, Analisis Pertanggungjawaban Pidana Bagi Pelaku Tenaga Pendidik dalam Melakukan Kejahatan Pencabulan terhadap Anak (Studi Putusan Nomor 75/PID.SUS/2020/PN Metro)

\section{Saran}

Selanjutnya peneliti mengemukakan saran-saran yang meyangkut hal-hal yang berkaitan dengan skripsi ini sebagai bahan pertimbangan bagi semua pihak yang bersangkutan, yaitu:

1. Kepada kuasa diharapkan bisa melenyapkan konten-konten yang berbau pornografi hormat ambang sarana cetak maupun elektronik karena babak tertera adalah diryah tunggal bagian yang mengakibatkan terjadi pelanggaran. Dengan dilakukan gerakan tertera, bertekad bisa menyumbat ataupun menyurutkan tindak pidana pelanggaran terhadap bocah dibawah usia.

2. Kepada kebanyakan diharapkan kepada lebih mengintensifkan mentalitas, moralitas, dan kepercayaan nilai mengedalikan jasmani agar tidak mudah terusik kepada mengamalkan suatu babak atau gerakan yang hisab hormat yang buntutnya akan menyusahkan dirinya sendiri. Selain itu kebanyakan juga harus lebih tafsir dan bekerja bagian dalam babak menyumbat terjadi pelanggaran bocah dibawah usia pakai memberitakan menjelang penjuru yang berhak jika memaklumi adanya tindak pidana pelanggaran terhadap bocah dibawah usia.

\section{DAFTAR PUSTAKA}

\section{Buku}

Adami Chazawi. 2002, SH. Pelajaran Hukum Pidana Bagian I.Jakarta: Raja Grafindo Persada.

Adami Chazawi. 2010. Kejahatan Terhadap Tubuh dan Nyawa. Rajawali Pers. Jakarta.

Agus Rusianto. 2015. Tindak Pidana dan Pertanggungjawaban Pidana, Tinjauan Kritis Melalui Konsistensi antara Asas, Teori, dan Penerapannya. Surabaya. Kencana.

Ahmad Nindra Ferry. 2002. Efektifitas Sanksi Pidana Dalam Penanggulan Kejahatan. Psikotropika. Kota Makassar. Perpustakaan Unhas. Makassar.

Andi Hamzah. 2009. Terminologi Hukum Pidana. Sinar Grafika. Jakarta.

Bambang Waluyo. 2000. Pidana dan Pemidanaan. Sinar Grafika. Jakarta.

Bambang Waluyo. 2000. Pidana dan Pemidanaan. Sinar Grafika. Jakarta.

Maidin Gultom.2008 Perlindungan Hukum Terhadap Anak dalam Sistem Peradilan Pidana Anak di Indonesia.Refika Aditama Bandung.

Mahrus Ali. 2011. Asas-Asas Hukum Pidana. Sinar Grafika. Jakarta.

M. Nasir Djamil.2013.Anak Bukan Untuk Dihukum. Sinar Grafika,

Moeljatno.2008. Asas-Asas Hukum Pidana. Rineka Cipta. Jakarta.

Moeljatno. 2008. Asas-Asas Hukum Pidana. Rineka Cipta. Jakarta.

Moeljatno. 2005. Asas-asas Hukum Pidana. Bina Aksara. Jakarta.

Muladi dan Dwidja Priyatno. 2009. Pertanggungjawaban Pidana koorporasi. Kencana Media Group. Bandung.

R.Soersono. 1992. Pengantar Ilmu Hukum. Sinar Grafika. Bandung.

Suteki. 2013. Desain Hukum di Ruang Sosial.Thafa Media. Yogyakarta.

Wirjono Projodikoro. 2003. Tindak Pidana Tertentu di Indonesia. Refika Aditama. Bandung.

Waluyadi.2009. Hukum Perlindungan Anak. CV Mandar Maju. Bandung.

\section{Perundang-Undangan Dan Peraturan Lain}

R. Soesilo. 1989. Kitab Undang-Undang Hukum Pidana. Bogor: Politeia

\section{Sumber Lain}

Dwi Nanda Saputra, SH. MH ( Kasipidun ), Wawancara, Metro 06 Januari 2021

Rakhmad Fajeri, S.H., M.H. (Majelis Hakim), Wawancara, Metro 27 Desember 2020 